\title{
ПИТАННЯ СОЦАЛЬНОЇ ІСТОРІЇ БОЛГАРІЇ У ТВОРЧОМУ ДОРОБКУ С. І. СІДЕЛЬНИКОВА
}

\author{
Н. І. Самойленко
}

Самойленко Н. І. Питання соціальної історії Болгарії у творчому доробку С. І. Сідельникова. У статті в межах базових концептів соціальної історії розглядається висвітлення відомим харківським болгарознавцем С. І. Сідельниковим питань визвольного антиосманського руху болгарського народу на останньому етапі боротьби за незалежність. Автор доходить висновку, що розвідки вченого є актуальними з огляду на з'ясування причин успіху у становленні національної державності.

Ключові слова: соціальна історія; історіографія; теорія історичного знання; болгарське національне Відродження; славістика.

Самойленко Н. И. Вопросы социальной истории Болгарии в творчестве С. И. Сидельникова. В границах базовых концептов социальной истории анализируется изучение известным харьковским болгаристом С. И. Сидельниковым вопросов освободительного антиосманского движения болгарского народа накануне завоевания независимости. Автор делает вывод о несомненной актуальности исследований ученого в связи с уяснением всего комплекса причин успеха в деле основания национальной государственности.

Ключевые слова: социальная история; историография; теория исторического знания; болгарское национальное Возрождение; славистика.

Samoylenko N. I. The Issues of Social History of Bulgaria in S. I. Sidelnikov's Papers. Basing on the principal concepts of social history the article analyzes the study of the national liberation anti-Ottoman movement of the Bulgarian people on the eve of independence in the research of well-known Kharkiv historian S. I. Sidelnikov. The author comes to conclusion that ones have undoubtedly relevance to clarify the entire complex of reasons for the success in national independent state formation.

Keywords: social history; historiography; theory of historical knowledge; Bulgarian national Revival; Slavonic studies.

Завдання репрезентації української історичної науки у світовій науковій традиції неминуче ставить у порядок денний питання щодо характеру та змісту набутого вітчизняними фахівцями досвіду. Адже він може служити певним підгрунтям до імплементації новацій та збереження наступності історичного знання. У повній мірі це стосується й болгаристичних розвідок як складової частини славістичних студій. Інтерес до них наукової громадськості є загальновідомим та всіляко підтримується, у тому числі завдяки діяльності Міжнародного комітету славістів.

Поступ вітчизняної болгаристики тісно пов'язаний з одним із представників іiї харківської школи Степаном Івановичем Сідельниковим (1916-1977). Розквіт його творчості у часі збігся із значними змінами у розвитку історичного знання. Ці зміни, пов'язані із лібералізацією другої половини 1950-х - першої половини 1960-х рр. та поступовим згортанням іiі у подальшому, у вітчизняній науці вже проаналізовано1. Безсумнівно, вони не могли не відобразитися у розвідках вченого. Адже через особистість історика не тільки відтворюється минуле, але й сучасність. У світовій науці згаданий період був позначений започаткуванням 3 кінця 1950-х рр. формування нового напряму - так званої «нової соціальної історії» ${ }^{2}$. Ї̈ї предметно-тематичне поле та дослідницькій інструментарій зазнавали постійних змін. У 1970-ті pp. вона вже виступала лідером у методологічному оновленні історії${ }^{3}$. При цьому діапазон проблем, якими вона займалася, залишався не чітко визначеним, але масові соціальні рухи різної забарвленості, а також життя класів та соціальних груп ніколи не випадали 3 кола іiї інтересів ${ }^{4}$. Соціальну історію завжди цікавили 3 одного боку конкретні соціальні явища, а з іншого - макропроцеси (масові та довготривалі соціальні процеси, революції, війн, тощо). За добу свого розквіту цей науковий напрям, спираючись на досвід попередників, які з'ясували особливості соціальних структур, відкрив 
механізми зв'язку індивідуального досвіду з діяльністю соціальних спільнот. За спостереженнями відомого соціального історика американського вченого Ч. Тіллі, встановивши цей зв'язок, соціальна історія сприяла розквіту економічної історії, дослідженню історичних аспектів сім'ї, демографії, масових народних рухів та повстань, освіти та здоланню неписьменності, міграційних процесів, злочинності, життя різних вікових груп та спільнот і навіть прогресу історичної урбаністики

Отже, соціальні історики не тільки декларували наміри, проте й конструювали минуле майже всієї соціальної реальності При цьому вони концентрували зусилля на вивченні життя звичайних людей (але не елітних груп, тобто розуміли історичний процес «знизу на гору»), акцентували також на аналізі різного роду факторів і причин, які обумовлювали групову поведінку. Це гранично широке тлумачення предметно-тематичного поля соціальної історії не могло не привести до нового його визначення та виокремлення нових історичних дисциплін (демографічної історії, історії дитинства та старості, гендерної історії, тощо) наприкінці $1970-x$ рр. ${ }^{6}$.

Широке коло вітчизняних істориків тоді було ізольованим від поступу світових наукових трендів. Проте внутрішня логіка розвитку науки спрямовувала їх пошук до тих питань, які загально визнано намагалася розв'язати саме соціальна історія. Не був виключенням $з$ цього доробок С. І. Сідельникова, в центрі наукових інтересів якого завжди була доба болгарського національного Відродження. Творчість вченого неодноразово привертала увагу істориків ${ }^{7}$. А. О. Сайпанова присвятила йому дисертаційне дослідження у 2012 р. та монографію ${ }^{8}$. Проте проблеми соціальної історії балканської країни на останніх етапах іï боротьбі за незалежність в інтерпретації харківського вченого ще не набули достатнього вивчення. У даній розвідці на підгрунті доступних автору джерел зроблено спробу надолужити цю прогалину.

У численних статтях та трьох оприлюднених монографіях ${ }^{9}$ вченого в межах загально визнаних концептів соціальної історії зафіксовані результати наукових пошуків і дискусій (про чорбаджійство, характер селянських повстань середини XIX ст., ідеологію та лідерство у революційному русі, соціальний склад й чисельність революційних організацій) та вказані напрями подальшого вивчення актуальних проблем масового національно-визвольного антиосманського руху у Болгарії. Вивчаючи болгарську спільноту напередодні досягнення незалежності, вчений у відповідності до методологічних вимог того часу перш за все звертався до аналізу соціальних верств, груп та лідерів - носіїв визвольних ідей. Говорячи про соціальний склад визвольного руху, дослідник, як й інші вітчизняні фахівці тієї доби, оперував термінами «народ» та «трудящі». 3 одного боку, такій підхід відображав слабкий ступень диференціації болгарського суспільства, неповної з точки зору передумов модернізації його соціальної структури ${ }^{10}$, а 3 іншого - став результатом недостатнього дослідження понять «народ» та «соціальна група» в радянській науковій традиції ${ }^{11}$. Зазначені обставини, вочевидь, на могли не вплинули й на з'ясування статусу та сутності чорбаджійства.

«Народ» у розвідках С. І. Сідельникова непорушно пов’язувався з трудовою діяльністю. Звідси випливала необхідність звернення до його економічного становища на останньому етапі боротьбі за незалежність. Трудова активність та місце у суспільному розподілі праці, таким чином, виступали своєрідним критерієм вододілу між окремими соціальними групами та верствами у болгарському суспільстві з незначним ступенем майнової диференціації. У цьому зв'язку заслуговує на увагу аналіз селянства та ремісництва, трудових прошарків міста. Образ цих соціальних груп відтворений через з'ясування економічного становища, соціальних прагнень, протестувальних настроїв ${ }^{12}$. С. I. Сідельникову належить пріоритет у встановлені зв'язку антифеодальної боротьби селянства 3 вирішенням завдань визвольного руху в середині XIX ст. ${ }^{13}$. Більш докладно описаний статус заможних верств. Здебільшого вони позиціонуються вченим як болгарська буржуазія (торгово-промислова, сільська, дрібна). Це досягається завдяки з'ясуванню не тільки іїі ідеологічного та політичного вибору, але й соціальної поведінки та побоювань, лідерства (коливання між просвітництвом та революційністю $)^{14}$. Досліджуючи соціальну структуру болгарського суспільства напередодні визволення, вчений окремо говорить про становище великої буржуазії ${ }^{15}$. Як правило, у розвідках 1960-1970-х рр. iіï існування було загальновизнаним. 3 точки зору змісту сучасного знання, яке вважає болгарське суспільство до Першої світо- 
вої війни аморфним ${ }^{16}$, твердження про наявність цієї соціальної групи у зазначену добу виглядає дещо архаїчно.

На окрему увагу заслуговує питання про чорбаджійство у висвітленні С. І. Сідельникова. Вчений зачепив надзвичайно важливу тему, до якої, за спостереженнями Н. Н. Червенкова, неодноразово зверталися дослідники у подальшому ${ }^{17}$. Тривалий час соціальна природа цієї верстви залишалася не зрозумілою: адже сам термін «чорбаджія» використовувавсяв історичних джерелах у різних сенсах ${ }^{18}$. Аналіз їі економічного становища та ставлення до визвольного антиосманського руху виявився достатнім для спростування тези про феодальну природу чорбаджіїв. Науковець пояснив, що саме використання ними архаїчних форм експлуатації вводило в оману дослідників при визначені соціальної приналежності чорбаджіїв. Друга причина труднощів у з'ясуванні ії̈ соціальної природи полягала у їі тісних зв'язках з існуючими на той час (тобто за добу кризи ленно-спахійської системи в Османській імперії) усіма видами соціальних відносин. Зазначаючи, що чорбаджії займалися лихварством, були земельними власниками, а в системі османського панування займалися відкупом податків, С. І. Сідельников вважав кінець XVIII - першу половину XIX ст. часом посилення їх соціальних позицій. Під маскою багатіїв вчений побачив й соціальні цінності чорбаджіїв - гроші та попрання етичних норм традиційного суспільства ${ }^{19}$, яким, безсумнівно, було на той період болгарське суспільство. Дослідження харківського вченого сприяли ствердженню розуміння буржуазної природи цієї верстви, пов'язаної економічно та політично $з$ усією системою османського панування ${ }^{20}$. Отже, соціальна структура болгарського суспільства конструювалася у відповідності до тогочасних теоретичних та ідеологічних уявлень у вітчизняній науці, які й забезпечували «когерентність інформаційного шару та переконливість» ${ }^{21}$ історичного наративу.

Для соціальної історії на всіх іiї етапах характерним було з'ясування ролі держави у житті суспільства. Звертаючись до цього сюжету, С. І. Сідельников зупинився на характеристиці османського панування в болгарських етнічних землях та ролі танзимату для болгарського суспільства. Він послідовно обстоював думку (про це неодноразово згадували дослідники наукового спадку харківського вченого) $)^{22}$, що це панування було добре впорядкованою системою свавілля адміністрації, поліції та суду османської імперії та піддав критиці позитивний вплив танзимату на політичний та економічний розвиток Болгарії. Останнє твердження виявляється актуальним й сьогодні. Адже на тлі аналізу освітніх реформ часів танзимату мають місце спроби ствердити більш нейтральні його характеристики $з$ огляду на позитивну реакцію найбільш заможних верств болгарського суспільства на гуманітарні проекти Мідхат-паші ${ }^{23}$.

Зв’язок індивідуального досвіду з груповою діяльністю в межах етнічної спільноти добре простежується у історико-біографічних розвідках харківського вченого, зокрема у виданій у 1959 р. першій монографії, присвяченій Г. Раковському (на це вже звертала увагу А. О. Сайпанова ${ }^{24}$ ), та статтях про В. Левського ${ }^{25}$ і Л. Каравелова ${ }^{26}$. Формування особистості цих лідерів подається на тлі тих подій та процесів в країні, що й складали зміст та сутність відродженського процесу.

Однією з типових особливостей нової соціальної історії впродовж 1960-1970-х рр. було звернення до квантитативних методик в історичних розвідках, тобто до з'ясування кількісних характеристик минулого соціальної реальності ${ }^{27}$. С. І. Сидельніков стояв біля витоків їх запровадження в практику вітчизняної болгаристики. Зазвичай, статистико-математичні методи застосовувалися для вивчення соціально-економічних проблем та соціально-класової структури. Вчений-новатор розповсюдив сферу їх уживання на болгарський визвольний антиосманський руху. Завдяки цьому вдалося з'ясувати головну причину гострої ідейної та організаційної боротьби у першому Болгарському революційному центральному комітеті - відмінності у соціальному складі революційних організацій всередині Болгарії та в еміграції ${ }^{2}$.

В розвитку історичної науки завжди важливим є звернення до творчого спадку дослідників минулого. Адже їх розвідки виявляються співзвучними сучасному розумінню «одвічних» проблем історії і навіть до певного ступеня передбачають звернення до них. У повній мірі це стосується праць С. І. Сидельнікова. Вони торкалися тих питань соціальної історії Болгарії, які загальновизнано вважаються базовими іiі концептами. Це, безсумнівно, диктувалося не тільки пошуком вченого, але й внутрішньою логікою розвитку іс- 
торичної болгаристки. Тематика історичних розвідок науковця почасти кореспондується 3 провідними тенденціями розвитку соціальної історії як наукового напряму впродовж 1960-1970-х pр. у світі взагалі. Загальновизнано, що історія Болгарії як у радянському, так й болгарському ії варіантах у зазначений період мала заполітизований характер. Проте 3'ясування докладної та неупередженої картини болгарського національного Відродження як історичної доби неминуче виводило дослідника за межі політичної кон'юнктури. Спостереження вченого за соціальним складом визвольного антиосманського руху в Болгарії не втратили своєї актуальності й зараз на тлі дискусій про співвідношення внутрішніх та зовнішніх факторів у вирішенні долі болгарського народу під час російсько-турецької війни 1877-1878 рр. ${ }^{29}$. Вони роблять свій внесок у ствердження думки про активну позицію болгарської спільноти у боротьбу за власне визволення. Вочевидь у цьому зв'язку буде доречним висловити припущення про те, що розвідки харківського історика представлятимуть інтерес й надалі. Інвазії у дослідницьке поле соціальної історії у працях C. I. Сидельнікова дозволяють по-новому поглянути на проблему створення національної державності. Адже вони наближають до відповіді на складне наукове питання у галузі соціо-гуманітарного знання: «Чому одні проекти національних держав виявилися успішними, в той час як інші - ні?». Загальновизнаним $\epsilon$, що осередки різного роду політичних інституцій передували національній державності. Проте розвідки вченого доводять наступне: наявність певного типу лідерів цих інституцій (зокрема, Болгарського центрального революційного комітету, який фактично виконував функції політичної партіі), а саме - лідерів, здатних бути поборниками національної ідентичності, виступає не менш важливою умовою торжества незалежності, ніж інші.

${ }^{1}$ Віднянський C. В. Рецепції всесвітньої історії на сторінках «Українського історичного журналу» // Український істричний журнал (далі - УІЖ). 2007. № 6. С. 166-180.

2 Делургьян Г. Военно-налоговая теория государства. Предисловие // Тилли Ч. Принуждение, капитал и европейские государства. 990-1992 гг. / Пер. с англ. Т. Б. Менской. М., 2009. C. 10. URL: http://www.prognosis.ru/lib/Tilli_\%283\%29.pdf (Дата звернення: 5.05 2016).

${ }^{3}$ Савельева И. М., Полетаёв А. В. Теория истрического знания. СПб.: Алетейя, 2008. С. 114.

${ }^{4}$ Eley $G$. Is All the World a Text? From Social History to the History of Society. Two Decades Later. CSST CRSO Working Paper \#55. Paper \#445 October, 1990. P. 7. URL: https://deepblue.lib.umich.edu/ bitstream/handle/2027.42/51212/445.pdf?sequence=1 (Дата звернення: 03.06.2016).

${ }^{5}$ Tilly $C$. The Old New Social History and The New Old Social History. Paper // Conference on New Direction in History, State University of New York at Buffalo, 3-5 October, 1980. P. 30. URL: http:// deepblue.lib.umich.edu/bitstream/handle/2027.42/50992/218.pdf (Дата звернення: 03.06.2016).

${ }^{6}$ Савельева И. М., Полетаев А. В. Теория истрического знания. С. 115.

${ }^{7}$ Козак В. М. Вшанування проф. С. І. Сидельнікова з нагоди його 60-річчя // УІЖ. 1976. № 6. С. 157; Чернявский Г. И. Исследования С. И. Сидельникова по проблеме национально-освободительного движения болгарского народа // Советское славяноведение. 1980. № 2. С. 84-92; Чернявский Г. И., Чувпило А. А. Разработка проблем национально-освободительного движения болгарского народа (в 60-70-х гг. ХІХ в.) в трудах С. И. Сидельникова // Вопросы новой и новейщей истории. Вып. 25. Харьков: Вища школа, 1979. С. 125-129; Чернявський Г. Й., Чорній В. П. Розробка проблеми болгарського національно-визвольного руху в працях С. І. Сидельнікова // Проблеми слов'янознавства. Вип. 20. Львів: Вища школа, 1979. С. 96-102; Пугач Е. П. Профессор С. И. Сидельников - выдающийся педагог и организатор науки //Дриновський збірник /Дриновски сборник. Т. ІІ. Харків-Софія: Академічне видавництво «Проф. Марин Дринов», 2013. С. 279-282; Co$x a н ь$ П. С. Слово про Степана Івановича Сидельнікова - видатного вченого-болгариста, мужню і прекрасну людину // Там само. С. 283-287; Самойленко Н. И. Творческое наследие С. И. Сидельникова и современная историческая наука // Там само. С. 24-28; Червенков Н. Н. С. И. Сидельников - исследователь болгарского Возрождения // Там само. С. 288-289; Сайпанова А. А. Неопубликованные монографии С. И. Сидельникова по истории болгарского Возрождения // Там само. Т. IV. Харків-Софія: Академічне видавництво «Проф. Марин Дринов», 2011. С. 58-65.

${ }^{8}$ Сайпанова А. О. Науково-педагогічна діяльність С. І. Сідельникова: автореф. ...дис. канд. іст. наук. Дніпропетровськ, 2012. 20 с.; Сайпанова A. А. Историк-болгарист С. И. Сидельников. Научная и педагогическая деятельность. Харьков: Харьков. национ. ун-т им. В. Н. Каразина, 2016. 211 с.

${ }^{9}$ Сідельников С. I. Болгарський революціонер Георгій Раковський: життя і діяльність. 1821-1866. Харьков, 1959. 174 с.; Його ж. Борьба течений в Первом Болгарском революционном центральном комитете. Харьков, 1962. 116 с.; Його ж. Болгарский революционный центральный комитет (18691872). Харьков, 1970. 176 с. 
${ }^{10}$ Гришина Р. П. Лики модернизации в Болгарии в конце XIX - начале XX вв. (бег трусцой по пересеченной местности). Серия «Человек на Балканах». М., 2008. С. 5; Гришина Р. П. Процессы модернизации и роль государства в них // Дриновській збірник // Дриновски сборник. Т. III. ХарківСофія: Академічне видавництво «Проф. Марин Дринов», 2009. С. 279-282.

${ }^{11}$ Барулин В. С. Социальная жизнь общества: вопросы методологии. М, 1987. С. 14-15, 24, 29.

${ }^{12}$ Сидельников С. И. Болгарский революционный центральний ... С. 6, 17, 18; Його ж. Г. Раковський... С. 7-8, 10-11.

13 Червенков Н. Н. Вказ. праця. С. 289, Сайпанова А. О. Науково-педагогічна діяльність С. I. Сідельникова. С. 13.

${ }^{14}$ Сидельников С. И. Борьба течений... С. 11,$14 ;$ Його ж. Болгарский революционный центральный ... С. 5, 6; Його ж. Г. Раковський ... С. 156.

${ }^{15}$ Сидельников С. И. Болгарский революционный центральный ... С. 6.

${ }^{16}$ Гришина Р. П. Лики модернизации в Болгарии в конце XIX - начале XX вв. С. 17.

17 Червенков Н. Н. С. И. Сидельников - исследователь болгарского Возрождения. С. 288.

18 Чорбаджия. URL: http://enc-dic.com (Дата звернення: 13.06.2016).

${ }^{19}$ Сидельников С. I. Г. Раковський... С. 26-27.

${ }^{20}$ Сидельников C. I. До питання про класовий характер чорбаджійства в Болгарії в період турецького панування // Учен. записки Харківськ. ун-ту. Т. 69. Труди історич. факультету. Т. 4. Харків: Вид-во Харк. ун-ту, 1956. С. 189-203.

21 Топольський Є. Як ми пишемо і розуміємо історію. Таємниці історичної нарації / Пер. 3 польськ. Н. Гончаренко. Київ: «К.І.С», 2012. С. 361.

${ }^{22}$ Сайпанова А. О. Историк-болгарист С. И. Сидельников. С. 128.

${ }^{23}$ Маркова И. К истории реформы образования в Дунайском вилайете в 60-е гг. ХІХ века // България, Балканите и Русия. XVIII-XIX век. Българо-руски научни дискусии. София, 2011. С. 229-244.

${ }_{24}$ Сайпанова A. O. Политическая деятельность Г. С. Раковского в освещении профессора С. И. Сидельникова // Българите в Северното Причерноморие. Изследвания и материали. Т. 10. Одеса-Велико Търново: Фабер, 2009. С. 127-135.

${ }^{25}$ Сідельников C. I. Початок революційної діяльності Васила Левського // Учен. зап. Харк. ун-ту. Т. 101. Труди істор. ф-ту. Т. 7. Харків: Вид-во Харк. ун-ту, 1959. С. 27-49; Його ж. Роль двох поїздок Василя Левського в Болгарію (груд. 1868 - серп. 1869 рр.) у створенні Першого болгарського революційного комітету // Питання нової та новітньої історії. К: Вища школа, 1965. № 1. С. 97-109.

${ }^{26}$ Сидельников С. Участието на Любен Каравелов в руския периодичен печат // Исторически преглед. 1962. № 5. С. 66-84.

${ }^{27}$ Gallant N. Long Time Coming, Long time Gone: the Past, Present and Future of Social History // Historien. 2012. Vol. 12. P. 9-20. URL: http: // epublishing.ekt.gr (Дата звернення: 03.06.2016).

${ }^{28}$ Сидельников С. И. О численном и социальном составе болгарских революционных организаций в 1869-1873 гг. // Историко-социологические исследования (на материалах славянских стран). М.: Наука, 1970. С. 254-283.

29 Петков П. С. Преди сто и повече години. Изследвания и очерци по нова история на България. Велико Търново: Университетско издтателство „Св. св. Кирил и Методий“, 2009. С. 99. 